\title{
Functional Equivalents of the Border, Sovereignty, and the Fourth Amendment
}

The fourth amendment's restrictions on searches do not apply at the nation's borders. Law enforcement agents may search any individual entering the country even without a warrant or a showing of probable cause. ${ }^{1}$ According to the Supreme Court, this border search exception may apply with equal force away from the actual border at locations that are "functional border equivalents." The Court, however, has never defined a functional border equivalent or set forth the scope of searches it would permit at such a location.

The two circuits most closely concerned with these questions have provided quite different answers. The Fifth Circuit has permitted warrantless searches at "distant" border equivalents-those areas where a majority of the traffic through a checkpoint is international. ${ }^{2}$ The Ninth Circuit has limited warrantless searches to "virtual" border equivalents-those areas where all but an insignificant portion of the traffic is international. ${ }^{3}$ In practice this disagreement translates into a striking difference in the kinds of searches permissible in near-border areas within these two circuits. ${ }^{4}$

1 For a discussion of the development of the border search exception to the fourth amendment, see infra notes 10-17 and accompanying text.

This comment uses the term "border search" in a very narrow sense. The term refers only to routine searches by customs or border patrol agents conducted pursuant to statutory authority but without the probable cause or warrant safeguards otherwise required by the fourth amendment. The paradigm customs search involves the routine opening and search of travelers' luggage, while the paradigm immigration search involves the search of the trunk of an automobile. This comment does not address the question of the reasonableness of more intrusive border searches such as strip searches or body cavity probes. These have been amply discussed in the literature. See, e.g., Ittig, The Rites of Passage: Border Searches and the Fourth Amendment, 40 TENn. L. REv. 329 (1973); Note, From Bags to Body Cavities: The Law of Border Search, 74 Colum. L. Rev 53 (1974) [hereinafter cited as Note, Bags to Body Cavities]; Note, Border Searches and the Fourth Amendment, 77 Yale L.J. 1007 (1968) [hereinafter cited as Note, Border Searches].

2 See United States v. Alvarez-Gonzalez, 561 F.2d 620 (5th Cir. 1977), discussed infra text accompanying notes $27-31$.

${ }^{3}$ See United States v. Bowen, 500 F.2d 960 (9th Cir. 1974), aff'd on other grounds, 422 U.S. 916 (1975), discussed infra text accompanying notes 32-35.

"The importance of the definition of a "functional equivalent" of the border is apparent, for example, when one considers the magnitude of the immigration problem. There are 
This comment criticizes the current approaches to functional border equivalence and suggests an alternative. Part $I$ traces the development of both the border search exception and the concept of functional border equivalence. The approaches of the Fifth and Ninth Circuits are shown to suffer from the Supreme Court's failure to explain sufficiently the underlying purposes of the border search exception. As a result, the Fifth Circuit defines functional border equivalence too broadly, the Ninth Circuit too narrowly. Part II suggests that the border search exception in fact arises out of the sovereign nation's special interests in activities at its perimeter. At the actual border these interests are sufficiently strong to overcome any individual interests in privacy and autonomy protected by the fourth amendment.

Part III reformulates functional border equivalence in light of this understanding. It shows that sovereign and individual interests vary with the location and purpose of the search, and suggests that a theory of functional border equivalence must balance these interests in any given context. The comment borrows interestbalancing methodology from the Court's jurisprudence of administrative searches to define what the fourth amendment should require at "distant" border equivalents in the context of immigration and customs searches. Because sovereign and individual interests differ in these two situations, the comment concludes that immigration searches at distant border equivalents should be permitted under reduced probable cause and warrant requirements but that customs searches require full fourth amendment safeguards.

\section{The Development of the Border Search Exception and The Concept of Functional Border Equivalence}

\section{A. The Border Search Exception}

The fourth amendment prohibits "unreasonable" searches and seizures. ${ }^{5}$ According to the Supreme Court, a search is always rea-

\footnotetext{
between 10 and 12 million illegal aliens in the United States. In 1983 the Immigration and Naturalization Service (INS) apprehended over 1.1 million illegal aliens, see U.S. DEP'T oF Commerce, Statistical ABstract of the United States 91 (1985), about one-quarter of them at purported functional border equivalents. INS Border Patrol Summary Report (Oct. 1983-Sept. 1984) (on file with The University of Chicago Law Review). This required examining approximately 5,489,000 conveyances, including 3,861,000 automobiles, and questioning over 14 million people. Statistical ABstract of the United States, supra, at 91.

s The right of the people to be secure in their persons, houses, papers, and effects, against unreasonable searches and seizures, shall not be violated, and no Warrants shall issue, but upon probable cause, supported by Oath or affirmation, and particularly describing the place to be searched, and the persons or things to be seized.
} 
sonable when conducted in accordance with a warrant supported by probable cause. ${ }^{6}$ The probable cause requirement provides a framework for balancing the government's interest in the search, which depends primarily on the likelihood that it will reveal evidence of unlawful activity, against the individual's interests in privacy and autonomy. ${ }^{7}$ The warrant requirement ensures that this balancing is performed by disinterested judicial officers. ${ }^{8}$ In exceptional circumstances, however, the government's interest may be strong enough to eliminate the warrant and probable cause requirements. ${ }^{9}$

The Supreme Court has held that border searches constitute such an exceptional circumstance; the historical practice of warrantless searches and their acceptance at the time the Bill of Rights was adopted indicate that border searches are inherently "reasonable," and thus exempt from the fourth amendment's probable cause and warrant requirements. ${ }^{10}$ The acceptance of the border search doctrine is demonstrated by the fact that in 1789 the first Congress, which proposed the fourth amendment, also enacted a customs statute authorizing the warrantless search of any ship or vessel entering the United States. ${ }^{11}$

U.S. Const. amend. IV.

- See, e.g., Katz v. United States, 389 U.S. 347, 357 (1967); Johnson v. United States, 333 U.S. 10, 14 (1948).

- See generally Illinois v. Gates, 462 U.S. 213, 239 (1983) (relaxed standard for deciding whether informant's tip established probable cause achieves the "accommodation of public and private interests that the Fourth Amendment requires"); Zurcher v. Stanford Daily, 436 U.S. 547, 565 (1978) (requirement of probable cause "should afford sufficient protection" of newspaper's first amendment rights); Johnson v. United States, 333 U.S. 10, 14 (1948) (judicial officer must decide "[w] hen the right of privacy must reasonably yield to the right of search").

- Johnson v. United States, 333 U.S. 10, 14-15 (1948); see also Torres v. Puerto Rico, 442 U.S. 465, 471 (1979); Delaware v. Prouse, 440 U.S. 648, 655 (1979); Marshall v. Barlow's Inc., 436 U.S. 307,313 (1978).

- Exceptions to the warrant requirement have been "jealously and carefully drawn." Jones v. United States, 357 U.S. 493, 499 (1958). Probable cause is generally required, however, both when a warrant is necessary, see, e.g., Illinois v. Gates, 462 U.S. 213, 239 (1983), and even when a warrant may be dispensed with, see, e.g., United States v. Ross, 456 U.S. 798, 807-08 (1982) (automobile search); Chambers v. Maroney, 399 U.S. 42, 48 (1970) (same). In rarer instances, probable cause itself may even be dispensed with. The border search is one such instance. See United States v. Ramsey, 431 U.S. 606, 616-19 (1977). For other exceptions, see United States v. Villamonte-Marquez, 462 U.S. 579, 592-93 (1983) (probable cause not required for boarding of vessels in certain waters for inspections of documents); People v. Hernandez, 229 Cal. App. 2d 143, 150-51, 40 Cal. Rptr. 100, 104 (1964) (probable cause not required for searches of parolees and probationers); cf. Camara v. Municipal Court, 387 U.S. 523, 534-39 (1967) (probable cause standard relaxed for certain health, safety, and fire inspections).

10 United States v. Ramsey, 431 U.S. 606, 616-619 (1977).

11 The statute provided: 
On several occasions the Court has hinted at potential rationales for the border search exception which underlie the historical approach. For example, in 1886 the Supreme Court, in dictum, interpreted the actions of the early Congresses to mean that the drafters of the fourth amendment did not intend the probable cause and warrant requirements to reach border searches. ${ }^{12}$ In a later case, the Court suggested a different basis for the exception, observing that " $[t]$ ravellers may be . . . stopped in crossing an international boundary because of national self-protection reasonably requiring one entering the country to identify himself as entitled to come in, and his belongings as effects which may be lawfully brought in."13

While these two examples imply that something more than history lies behind the border search exception, the modern Court has been content to base its continued approval of the exception almost entirely on historical grounds without exploring more

That every collector, naval officer and surveyor, or other person specially appointed by either of them for that purpose, shall have full power and authority, to enter any ship or vessel, in which they shall have reason to suspect any goods, wares or merchandise subject to duty shall be concealed; and therein to search for; seize, and secure any such goods, wares or merchandise. . . .

Act of July 31,1789 , ch. $5, \S 24,1$ Stat. 29,43 . The adoption of similar customs laws by the second and fourth Congresses, see Act of Aug. 4, 1790, ch. 35, §§ 48-51, 1 Stat. 145, 170; Act of Feb. 18, 1793, ch. 8, § 27, 1 Stat. 305, 315; Act of March 2, 1799, ch. 22, §§ 68-71, 1 Stat. $627,677-78$, whose membership also included many of the original framers of the Constitution, further strengthens the argument that border searches have a historical acceptance equal to that of the fourth amendment.

In contrast, the first federal immigration regulation, which barred convicts and prostitutes, was not enacted until 1875. Act of March 3, 1875, ch. 141, 5 , 18 Stat. 477, 477-78. But cf. Act of Feb. 19, $1862 \S \S 2158-64,18$ Stat. 379 (prohibiting importation of Chinese and Japanese servants). This historical statutory distinction between authority for customs searches and authority for immigration searches was eliminated in 1971 when federal regulations empowered border agents to enforce both immigration and customs laws. 36 Fed. Reg. 13,410 (1971). This concurrent authority has been termed the "two hats" doctrine, United States v. McDaniel, 463 F.2d 129, 134 (5th Cir. 1972), cert. denied, 413 U.S. 919 (1973), and removes any statutory distinctions which might previously have existed between the customs and immigration search powers.

The current customs statute authorizes searches conducted by the Bureau of Customs under the supervision of the Treasury Department. The pertinent enforcement provisions are:

Any of the officers . . . may stop, search, and examine, . . . any vehicle, beast, or person, on which or whom he or they shall suspect there is merchandise which is subject to duty . . . and to search any trunk or envelope, wherever found, in which he may have a reasonable cause to suspect there is merchandise which was imported contrary to law, ...

19 U.S.C. $\$ 482$ (1982); see also 19 C.F.R. 162.5-162.7 (1985).

12 Boyd v. United States, 116 U.S. 616, 623 (1886).

${ }^{13}$ Carroll v. United States, 267 U.S. 132, 154 (1925). 
deeply the government's true underlying interests. Indeed, in United States $v$. Ramsey, ${ }^{14}$ an important recent decision on the exception, the Court emphasized that the "longstanding recognition that searches at our borders without probable cause and without a warrant are nonetheless 'reasonable' has a history as old as the Fourth Amendment itself." As Although susceptible to criticism, ${ }^{16}$ this historical justification has become the Court's standard reply to challenges to the border search exception. ${ }^{17}$

\section{B. Functional Border Equivalence}

1. Supreme Court Cases. The Supreme Court has also said, albeit in dicta, that the border search exception may apply to searches performed away from the actual border at "functional border equivalents." In Almeida-Sanchez $v$. United States, ${ }^{18}$ the Court gave two examples:

Whatever the permissible scope of intrusiveness of a routine border search might be, searches of this kind may in certain circumstances take place not only at the border itself, but at its functional equivalents as well. For example, searches at an established station near the border, at a point marking the confluence of two or more roads that extend from the border, might be functional equivalents of border searches. For another example, a search of the passengers and cargo of an airplane arriving at a St. Louis airport_after a nonstop flight from Mexico City would clearly be the functional equivalent of a border search. ${ }^{19}$

The Court did not, however, set forth a principle that relates these

14431 U.S. 606 (1977).

15 Id. at 619 (citation omitted).

16 See Note, Beyond the Border of Reasonableness: Exports, Imports and the Border Search Exception, 11 Hozstra L. REv. 733, 745-52 (1983) (contending that the juxtaposition of legislative enactment does not justify the abrogation of the fourth amendment since the customs statute was passed prior to the proposal of the fourth amendment); Note, Border Searches, supra note 1, at 1011 (arguing that historical standards of reasonableness are not applicable in a modern context); cf. Holmes, The Path of the Law, 10 Harv. L. REv 457, 469 (1897) ("It is revolting to have no better reason for a rule of law than that so it was laid down in the time of Henry IV.").

17 See United States v. Montoya de Hernandez, 105 S. Ct. 3304, 3309 (1985); Ramsey, 431 U.S. at 616-19; United States v. 12 200-Ft. Reels of Super 8mm. Film, 413 U.S. 123, 125 (1973); United States v. 37 Photographs, 402 U.S. 363, 376-77 (1971); cf. United States v. Villamonte-Marquez, 462 U.S. 579, 592-93 (1983) (approving a seaborne search on the same basis). But see infra note 38 and accompanying text.

18413 U.S. 266 (1973).

19 Id. at 272-73 (footnote omitted). 
examples to the border search exception. The Court held only that the search in the case at hand-a roving patrol on a highway twenty-five miles from the border-did not fall within the functional border search exception. ${ }^{20}$

Although Almeida-Sanchez contains the Court's only description of places that might qualify as functional border equivalents, two other cases bear on this issue and suggest the scope of permissible government conduct at near-border locations. In United States $v$. Martinez-Fuerte, ${ }^{21}$ the Court approved brief investigatory stops by border patrol agents without probable cause at fixed checkpoints that were conceded not to be functional border equivalents. ${ }^{22}$ Probable cause was not necessary, according to the Court, because the stop entailed only a limited intrusion, resulted in little stigmatization, and involved relatively little exercise of discretion by the agents. ${ }^{23}$ Conversely, in United States $v$. Ortiz, ${ }^{24}$ the Court required probable cause for searches by border patrol agents at checkpoints admitted not to be functional border equivalents, ${ }^{25}$ on the ground that searches are more intrusive than mere stops. The Court also thought these searches were more stigmatizing than stops because officers at the checkpoints exercised substantial discretion in singling out which cars to search. ${ }^{26}$

These cases provide at least some insight into a theory of functional border equivalence. In particular, they show that the probable cause and warrant requirements are necessary for border zone searches at locations that do not qualify as border equivalents. Martinez-Fuerte and Ortiz also indicate that such factors as the extent of intrusion, the resulting stigmatization, and the range of official discretion are relevant to fourth amendment analysis of searches near the border.

2. Circuit Court Approaches. Despite the dicta in AlmeidaSanchez, as well as the hints given in cases like Ortiz and Martinez-Fuerte, the circuit courts have struggled to interpret what the Supreme Court's decisions require for lawful searches

20 Id. at 273.

21428 U.S. 543 (1976).

${ }^{22}$ A stop is a brief detention for questioning. $I d$. at 555-56.

${ }^{23}$ Id. at 559-60; cf. United States v. Brignoni-Ponce, 422 U.S. 873, 884 (1975) (reducing the general probable cause requirement for stops by holding that to stop a vehicle roving border patrols need only be aware of specific articulable facts which give rise to a reasonable suspicion that the vehicle and its contents have entered the country illegally).

24422 U.S. 891 (1975).

25 Id. at 896-98.

${ }^{26}$ Id. at $895-97$. 
near the national borders. Although the case law on the border search exception is well established, the Court's purely historical approach to the doctrine leaves it largely unexplained. This has frustrated attempts to extend it to border equivalents through reasoning by analogy. Thus it is unsurprising that the Fifth and Ninth Circuits have taken quite different approaches to border zone searches.

The Fifth Circuit's definition of a functional equivalent of the border has emerged from a series of cases involving checkpoints in Texas, culminating in United States $v$. Alvarez-Gonzalez. ${ }^{27}$ There the court identified three relevant factors. First, the searches at a chosen location must be sufficiently unintrusive. This means that the checkpoint must " function like a permanent border checkpoint and not like [a] roving border patrol." "28 Only a permanent checkpoint provides fair notice and warning of its existence, and reduces the discretion that officials exercise in choosing which travelers to stop and search. Second, the ratio between international and domestic traffic through the checkpoint must be such that the interference with domestic traffic is relatively minimal. If the volume of international traffic clearly predominates, all travelers at the stop can be treated as though they have crossed the border. ${ }^{29}$ Finally, to be a functional border equivalent, the checkpoint must approximate the effect of one located at the border, and therefore must be capable of monitoring " portions of international traffic not otherwise practically controllable." "30 This aspect of the test allows the court both to evaluate the need of the government, for reasons of efficiency, to establish a checkpoint in a particular location and to consider the success of the checkpoint in apprehending aliens or confiscating drugs. ${ }^{31}$

${ }^{27} 561$ F.2d 620 (5th Cir. 1977). The earlier cases included United States v. Hart, 506 F.2d 887 (5th Cir.), vacated and remanded, 422 U.S. 1053 (1975), aff'd per curiam, 525 F.2d 1199 (5th Cir.), cert. denied, 428 U.S. 923 (1976); United States v. Calvillo, 537 F.2d 158 (5th Cir. 1976); United States v. Alvarez-Gonzalez, 542 F.2d 226 (5th Cir. 1976). See generally Note, Border Zone Search Law: The Search for a Definition of Functional Equivalents of the Border, 16 TEx. INT'L L.J. 260, 264-71 (1981) (examining several Fifth Circuit cases).

${ }^{28}$ Alvarez-Gonzalez, 561 F.2d at 622 (quoting United States v. Alvarez-Gonzalez, 542 F.2d 226, 229 (5th Cir. 1976)).

29 561 F.2d at 622-23. For examples of the unrestrictive nature of this requirement, see infra note 60 .

so 561 F.2d at 624 (quoting United States v. Alvarez-Gonzalez, 542 F.2d at 229).

s1 In Alvarez-Gonzalez the Fifth Circuit also indicated that the scope of the search is significant, although it did not consider it a part of the threefold test. Since a full-scale search for contraband is more intrusive than a search of the large compartments of an automobile for aliens, authorization for a full-scale search might require a reevaluation of whether a checkpoint was a functional border equivalent. See 561 F.2d at 624-25; Hart, 506 
The Ninth Circuit's approach offers a significantly narrower definition of functional border equivalence. In United States $v$. Bowen, ${ }^{32}$ the court defined the "function" of the border search as the regulation of border crossings. ${ }^{33}$ The court indicated that it considered the examples of functional border equivalents set out by the Supreme Court in Almeida-Sanchez to be nearly exhaustive. On this basis the court concluded that functional border equivalence exists only if the "search takes place at a location where virtually everyone searched has just come from the other side of the border." ${ }^{34}$ The court reasoned that since agents exercise discretion even at fixed checkpoints, the ratio of international traffic to domestic traffic should be determinative. ${ }^{35}$

\section{A Critique}

The Fifth and Ninth Circuits' different approaches to defining functional border equivalence indicate a need for a clearer understanding of the purposes of the border search exception. A purely historical approach, barren of analysis, is too conclusory to support either circuit's approach.

To illustrate, take the Fifth Circuit's test. One prong of that test requires functional border equivalents to have a majority of international traffic. Since history teaches that warrantless searches of people who have just crossed the border are per se reasonable, it can be argued that the government may conduct a border search at any checkpoint where more than half the traffic is international. At that checkpoint, the majority percentage of international traffic would make it more probable than not that any one person or car had recently crossed the border. ${ }^{36}$ This argument

F.2d at 895. Since Alvarez-Gonzalez, however, the Fifth Circuit has abandoned this distinction and included within the scope of permissible searches the routine examination of small compartments and luggage by border patrol agents. See United States v. Oyarzun, 760 F.2d 570 (5th Cir. 1985); United States v. Dreyfus-de Campos, 698 F.2d 227, 228-29 (5th Cir.), cert. denied, 461 U.S. 947 (1983); United States v. Salinas, 611 F.2d 128, 129-31 (5th Cir. 1980); United States v. Warren, 594 F.2d 1046, 1048 (5th Cir. 1979); cf. United States v. Cascante-Bernitta, 711 F.2d 36, 37-38 (5th Cir.) (approving a search by a customs agent at an airport), cert. denied, $104 \mathrm{~S}$. Ct. 252 (1983). This distinction between searches of large and small compartments is defended infra at notes 90-92 and accompanying text; see also United States v. Oyarzun, 582 F. Supp. 121, 123 (W.D. Tex. 1984), rev'd, 760 F.2d 570 (5th Cir. 1985).

${ }^{32} 500$ F.2d 960 (9th Cir. 1974), aff'd on other grounds, 422 U.S. 916 (1975).

${ }^{33}$ Id. at 965 .

${ }^{34}$ Id. (emphasis added).

${ }^{35} I d$. at $964-65$.

${ }^{36}$ A similar analysis can be found in the Supreme Court's treatment of "drug courier" profile cases. Drug courier profiles are a collected group of characteristics that drug enforce- 
would hold that an official has "probable cause" to search every person and car, regardless of whether they had in fact just crossed the border.

This argument is flawed, however, because it fails to take into account the interests of those individuals searched who have not crossed the border. The border search doctrine stands only for the proposition that, because of the long history of border searches, all searches at the border are "reasonable" under the fourth amendment; it is thus not necessary to consider the balance of public and private interests to determine that any search at the border is lawful. However, because a historical.approach relates only to searches at the border of individuals who have just crossed the border, it says nothing about how modern courts should balance government and private interests when a considerable number of people searched have not just crossed the border. As the searches move away from the border, the government's interest in searching international travelers is diluted by the introduction of traffic that is non-international, and the resulting balance of interests in any given search might be insufficient to support an exception from the probable cause and warrant requirements.

The Ninth Circuit's approach is no more compelling because it undervalues the government's interest in undertaking certain kinds of searches of international travelers. The fact that traffic at a checkpoint includes a significant number of domestic travelers does not eliminate this interest, nor is it clear that the history of the fourth amendment allows border searches only if "virtually all" travelers passing through a checkpoint just came from the border. Officials at a more distant near-border checkpoint might be more certain than not that a traveler had just crossed the border, but the Ninth Circuit's definition would prevent them from taking advantage of the border search exception to the fourth amendment. Again, because a pure historical approach to the border search ex-

ment agents have found to be common among drug couriers traveling in airports. See Florida v. Royer, $103 \mathrm{~S}$. Ct. 1319, 1339 n.6 (1983) (Rehnquist, J., dissenting). The profile may include such factors as nervous appearance, traveling without luggage, and changing airlines unnecessarily at a transfer point. See, e.g., United States v. Mendenhall, 446 U.S. 544, 547 n.1 (1980); United States v. Elmore, 595 F.2d 1036, 1039 n.3 (5th Cir. 1979) (listing eleven separate characteristics), cert. denied, 447 U.S. 910 (1980). Although the Court has not directly addressed the use of profiles, a majority apparently would allow them as a method of establishing the reasonable suspicion required to initiate an investigatory stop of a drug courier suspect. See Florida v Royer, 460 U.S. 491, 502 (1983) (plurality opinion of White, J., joined by Marshall, Powell and Stevens, JJ.); id. at 523-25 (dissenting opinion of Rehnquist, J., joined by Burger, C.J., and O'Connor, J.); United States v. Mendenhall, 446 U.S. 544, 563-65 (concurring opinion of Powell, J., joined by Burger, C.J., and Blackmun, J.). 
ception fails to explain the nature or the magnitude of the government's interest, it provides no basis for assessing this interest once the search occurs away from the border.

Therefore it appears that although history is thought to justify border searches, it does not aid in establishing their limits. A statistical measure of "probable cause" is meaningless if the underlying individual and governmental interests remain unexplained and unmeasured. As a result, the Ninth Circuit's approach errs on the side of requiring too great a governmental interest before establishing functional border equivalence. And although the Fifth Circuit's approach does attempt to weigh individual and governmental interests, at its outer limits it may label checkpoints as functional equivalents even though the government's interest is diluted below the level necessary to justify excepting a search from fourth amendment safeguards.

\section{The Sovereign Interest in Border Searches}

As noted previously, even though the Supreme Court now relies primarily upon a historical approach to justify the border search exception, this approach does not represent the Court's only statements on the subject. ${ }^{37}$ In several cases, the Supreme Court has indicated that what in fact lies behind the historical acceptance of the border search exception is the sovereign interest in maintaining territorial and national integrity. ${ }^{38}$

The Supreme Court has recognized that principles of sovereignty give the federal government plenary power to regulate immigration. Before The Chinese Exclusion Case, ${ }^{30}$ which upheld a law prohibiting all Chinese from entering the country, the Court found authority for congressional control of immigration in the foreign commerce clause of the Constitution. ${ }^{40}$ But in that case the

${ }^{37}$ See supra notes 13-17 and accompanying text.

ss See Torres v. Puerto Rico, 442 U.S. 465, 472-73 (1979) (basing the border search exception in part on the federal government's "inherent sovereign authority to protect its territorial integrity"); United States v. Ramsey, 431 U.S. 606, 616 (1977) (border searches are made "pursuant to the longstanding right of the sovereign to protect itself"); Carroll v. United States, 267 U.S. 132, 154 (1925) (border stops required because of "national selfprotection"). This sovereignty rationale has also been recognized by the lower federal courts. See, e.g., Garcia-Mir v. Smith, 766 F.2d 1478, 1484 (11th Cir. 1985) (relaxed constitutional enforcement at the border based on "the nation's interest in self-determination"); United States v. Oyarzun, 760 F.2d 570, 574 (5th Cir. 1985) (border search exception justified on the basis of "sovereign self-protection").

38 Chae Chan Ping v. United States, 130 U.S. 581 (1889).

10 Among Congress's enumerated powers are the powers to "regulate commerce with foreign nations" and to "establish a uniform rule of naturalization." U.S. CoNST. art. I, § 8, 
Court declared a more fundamental rationale: "Jurisdiction over its own territory . . . is an incident of every independent nation. It is a part of its independence. If [a nation] could not exclude aliens it would be to that extent subject to the control of another power."41 As such, the sovereign's power to exclude foreigners cannot "be granted away or restrained on behalf of any one."42

As these statements indicate, the sovereign's power over immigration is extremely broad. It includes the power to exclude only certain classes of immigrants, since it is an "accepted maxim of international law, that every sovereign nation has the power, as inherent in sovereignty, . . . to admit [foreigners] only in such cases and upon such conditions as it may see fit to prescribe." ${ }^{43}$ Indeed, "[o]ver no conceivable subject is the legislative power of Congress more complete than it is over the admission of aliens." ${ }^{44}$

The sovereign also has an inherent power to regulate foreign commerce by regulating customs, by enacting duties and tariffs, and by other means. ${ }^{45}$ The principle of sovereign rights was first applied to customs collections in Cross v. Harrison, ${ }^{46}$ where the Court stated:

It is very well understood to be a part of the laws of nations, that each nation may designate, upon its own terms, the ports and places within its territory for foreign commerce, and that

cls. 3, 4; see The Head Money Cases, 112 U.S. 580, 591-94 (1884) (reviewing cases establishing that Congress has the exclusive power to regulate commerce with foreign nations, including the transportation of immigrants).

11 The Chinese Exclusion Case, 130 U.S. at 603-04, quoted in Almeida-Sanchez v. United States, 413 U.S. 266, 291 (1973) (White, J., dissenting).

42130 U.S. at 609. For a criticism of such an absolute vision of this power, see Note, Constitutional Limits on the Power to Exclude Aliens, 82 CoLum. L. Rev. 957 (1982).

4s Nishimura Ekiu v. United States, 142 U.S. 651, 659 (1892); see also Act of March 3, 1875 , ch. $1, \S 5,18$ Stat. $477,477-78$ (the first federal immigration statute, which excluded only prostitutes and convicts); 2 Emmerich dE VATTEL, LAw of NATURE and Nations $\$ \$ 94$, 100 (4th ed. London 1811) (1st ed. London 1758) (the right to prohibit or condition entrance into a territory stems from the rights and domain of sovereignty).

${ }^{4}$ Kleindienst v. Mandel, 408 U.S. 753, 766 (1972) (quoting Oceanic Navigation Co. v. Stranahan, 214 U.S. 320, 339 (1909)).

This broad power was also noted in the Eleventh Circuit's recent opinion in Garcia-Mir v. Smith, 766 F.2d 1478 (11th Cir. 1985). There, the court rejected the claims of the "Mariel Boatlift" Cubans that they possessed constitutional rights that were infringed by their continued detention, and held that the "contours" of the Cubans' rights were largely left to legislative discretion. The court stated: "As the history of its immigration policy makes clear, this nation has long maintained as a fundamental aspect of its right to self-determination the prerogative to determine whether, and in what numbers, outsiders without any cognizable connection to this society shall be permitted to join it." Id. at 1484 .

is See supra note 11.

18 57 U.S. (16 How.) 164 (1853). 
any attempt to introduce foreign goods elsewhere, within its jurisdiction, is a violation of its sovereignty. ${ }^{47}$

The powers to control immigration and foreign commerce are members of a class of similar powers that inhere in the sovereign nature of the federal government even though they are not enumerated in the Constitution. ${ }^{48}$ In the classic case, United States $v$. Curtiss-Wright Export Corp., ${ }^{49}$ the Court acknowledged that certain powers necessary to the sovereignty of a nation had not been specifically delegated to the federal government by the Constitution. ${ }^{50}$ It then noted that since the states themselves were never sovereigns possessing external foreign powers, they could not have been the source of the federal government's external powers. Rather, the powers of external sovereignty are inherent and unenumerated powers that passed to the federal government from the British Crown via the confederation government. ${ }^{51}$ The Court has indicated that this class of unenumerated powers may be exercised as broadly as the other powers expressly granted to the federal government. ${ }^{.2}$

17 Id. at 196; see also 1 E. VATTEL, supra note 43 , $§ 90,92$ (sovereign states, as of natural right, may prohibit and regulate their foreign commerce).

18 See, e.g., Schuck, The Transformation of Immigration Law, 84 CoLum. L. REv. 1, 1821 (1984) (extraconstitutional nature of exclusion power); Note, supra note 42, at 966-74 (same).

49 299 U.S. 304 (1936).

so Id. at 318. Examples of other unenumerated powers include the power to recognize foreign governments and the power to acquire territory by treaty. See generally LouIs HENkin, EOREign Affairs and the Constitution, 16-17 (1972).

si Curtiss-Wright, 299 U.S. at 315-17. Although the historical basis of the view that the states were never individual sovereigns has been strongly criticized, see, e.g., HENkIN, supra note 50, at $284 \mathrm{n.10}$; Note, supra note 42 , at $969-74$ and authorities cited therein, the doctrine of extratextual foreign powers remains authoritative, see Perez v. Brownell, 356 U.S. 44, 57 (1958) ("The States that joined together to form a single Nation and to create, through the Constitution, a Federal Government to conduct the affairs of that Nation must be held to have granted that Government the powers indispensable to its functioning effectively in the company of sovereign nations."), overruled on other grounds, Afroyim v. Rusk, 387 U.S. 253 (1967); United States v. Glasser, 750 F.2d 1197, 1200 (3d Cir. 1984) (categorizing the right to regulate the border as an inherent power of sovereignty which passed to the United States upon the cessation of the exercise of sovereignty by Great Britain).

${ }^{32}$ Where sovereign powers do not infringe on the rights of American citizens the Court has found virtually no limit to their exercise. For example, the Court has recognized that the power to acquire territory by treaty, a nontextual power, includes the power to negotiate treaties whose provisions, if applied to the states rather than to the territories, would be unconstitutional. See Downes v. Bidwell, 182 U.S. 244, 253-57 (1901); id. at 345-46 (Gray, J., concurring). But see id. at 288-89 (White, J., concurring). The Court has treated the power to acquire territory by treaty or war as practically absolute. See American Ins. Co. v. Canter, 26 U.S. (1 Pet.) 511, 542 (1828); cf. Missouri v. Holland, 252 U.S. 416, 433 (1920) (ruling that treaty provisions are not subject to the same tenth amendment restrictions as acts of Congress since the power to deal by treaty with matters requiring national action is one 
When applied to the fourth amendment, the notion of sovereign powers makes sense of the border search exception. The federal government's power over immigration and foreign commerce is immense, and the nation's border is the primary locus at which that power must be exercised. The border search exception should be seen as recognizing that the government's sovereign interests at the actual border are so strong that they always outweigh the individual's privacy and autonomy interests in avoiding "unreasonable" searches. ${ }^{53}$ It is not obvious, however, that sovereign interests so clearly outweigh individual interests when the searches occur away from the border and may include individuals who have not just crossed the border. Functional border equivalence, then, becomes a matter of determining how those competing interests change away from the actual border.

which must " 'somewhere reside in every civilized government' ") (quoting Andrews v. Andrews, 188 U.S. 14, 33 (1903)). But cf. Reid v. Covert, 354 U.S. 1, 16 (1957) (holding that no treaty can "confer power ... on any ... branch of government which is free from the restraints of the constitution").

Even when the exercise of the sovereign power may infringe on the rights of American citizens, so long as the infringement occurs outside the United States the sovereign right has not been greatly limited. Thus, the Court has upheld Congress's power to institute taxation schemes for the territories which would be unconstitutional if applied to the states. See, e.g., Cincinnati Soap Co. v. United States, 301 U.S. 308, 323 (1937); Downes v. Bidwell, 182 U.S. 244, 287 (1901). Congress may also determine the status of territorial inhabitants, see Rabang v. Boyd, 353 U.S. 427, 432 (1957); Downes, 182 U.S. at 279, possibly denying them some of the protections of the Bill of Rights, see Downes, 182 U.S. at 277, 283. But see, e.g., Rodriguez v. Popular Democratic Party, 457 U.S. 1 (1982) (extending constitutional voting rights protection to Puerto Rican citizens). In addition, the Court has gone so far as to deem the power to govern territories acquired by treaty or conquest has been deemed to include the right to govern the reconstructed states so as to prevent a recurrence of insurrection. See Stewart v. Kahn, 78 U.S. (11 Wall.) 493, 506 (1870). In Stewart, a provision of an ex post facto federal statute that abrogated Louisiana's statute of limitations was upheld as an exercise of the war power, though it bore no clear relation to the prevention of rebellion. Id.

${ }^{53}$ Several commentators have argued that the fourth amendment's warrant requirement should apply to intrusive body searches at the border, see, e.g., Note, Bags to Body Cavities, supra note 1 , at $82-87$, but none has gone so far as to suggest that the border search exception itself be done away with. However, other fourth amendment doctrines whose original justifications gradually were submerged in favor of a historical argument have not been immune to Supreme Court reappraisal. See, e.g., Camara v. Municipal Court, 387 U.S. 523, 528-34 (1967) (requiring administrative search warrants), overruling Frank v. Maryland, 359 U.S. 360 (1959) (which approved warrantless administrative searches on historical grounds); cf. Katz v. United States, 389 U.S. 347, 351-53 (1967) (approving fourth amendment protection of phone conversations), altering Olmstead v. United States, 277 U.S. 438 (1928) (which limited the scope of fourth amendment protection to objects within the historical trespass doctrine). This comment's recognition of an underlying sovereignty rationale precludes such a reappraisal of the border search exception. 


\section{Applying the Sovereignty Rationale to Functional Border EQUIVALENTS}

\section{A. The Special Problem of Distant Border Searches}

In order to determine how a sovereignty-based approach to border searches relates to functional border equivalence, it is useful to classify near-border searches into two categories: virtual border searches and distant border searches. A virtual border search occurs at a location through which all or almost all of the traffic has just crossed the border. A distant border search occurs at a location where a significant portion of the traffic has just crossed the border. These two categories correspond to the tests adopted by the Ninth and Fifth Circuits, respectively.

With regard to virtual border searches, the recognition that the government's border interests are sovereignty-based indicates that these searches, like actual border searches, should be exempt from fourth amendment requirements. The circumstances at a virtual border are nearly identical to those at the actual border. ${ }^{54} \mathrm{Be}$ cause practically all the people searched at the virtual border have just crossed the border, the sovereign has the same interest in searching them as it would if the searches were conducted at the actual border. ${ }^{\mathrm{S5}} \mathrm{A}$ virtual border search, in fact, is almost identical to the international flight example used by the Supreme Court in Almeida-Sanchez.

In contrast, the overinclusiveness of distant border searches, which results from the significant amount of non-international traffic, changes the fourth amendment balance in two ways: it dilutes the government's interest in a search of any given individual, and it increases the possibility and extent of damage to an individ-

s4 Virtual border searches are by definition confined to areas where there are virtually no searches of noninternational travelers. Such a variation from the conventional concept of border searches can only be considered de minimis. Even the more restrictive Ninth Circuit has readily recognized that the factors involved in border searches change very little if the search is conducted close to the border. See supra notes 32-35 and accompanying text.

${ }^{B S}$ This is also the case when surveillance establishes with reasonable certainty that a particular vehicle has crossed the border and has not since had an opportunity to load or unload. In such cases, courts have permitted a search of the vehicle without a warrant or probable cause as if it had been stopped at the border. See, e.g., Alexander v. United States, 362 F.2d 379, 382 (9th Cir.), cert. denied, 385 U.S. 977 (1966); cf. United States v. Brennan, 538 F.2d 711, 721 (5th Cir. 1976) (allowing search of plane after surveillance following border crossing), cert. denied, 429 U.S. 1092 (1977). Failure to maintain surveillance defeats the presumption that conditions in the vehicle have not changed. See, e.g., Contreras v. United States, 291 F.2d 63, 65 (9th Cir. 1961). But see United States v. Terry, 446 F.2d 579, 581-82 (9th Cir.), cert. denied, 404 U.S. 946 (1971) (allowing brief breaks in surveillance); Alexander, 362 F.2d at $582-83$ (same). 
ual's privacy and autonomy interests resulting from the search. ${ }^{56}$ Clearly, the government's interest in any one search at a distant border checkpoint is lower than at a virtual border checkpoint. At a distant border, agents can hardly avoid searching many domestic travelers in whom the government has no special sovereigntyrelated interest whatsoever.

Moreover, the negative effects of government intrusions upon individuals are greater at distant border locations than at an actual border. Actual borders have an international legal status ${ }^{57}$ that puts travelers on notice that searches are likely to be made. This notice diminishes the travelers' expectation of privacy and may make it reasonable to presume that they implicitly have consented to a warrantless search upon their reentry into the country. ${ }^{58}$ The expectation that a search may occur also makes border searches less insulting and stigmatizing, thereby mitigating the injury they cause. ${ }^{59}$

Unlike actual borders, however, distant border equivalents have no international legal status. Distant checkpoints may be set up at sites where a substantial number of the people passing through the checkpoint have not crossed the international border. ${ }^{60}$ These distant checkpoints do not clearly give notice that limited warrantless searches may occur. Travelers who have not crossed the border thus cannot be thought to have given their implied consent to warrantless searches merely by traveling near the border. ${ }^{61}$ When singled out for search the individual may feel in-

so See supra text following note 36 and text accompanying note 28.

67 See Bernard Gilson, The Conceptual System of Sovereign Equality 181-84 (1984); see also United States v. Ramsey, 431 U.S. 606, 616 (1977) ("searches made at the border, pursuant to the long-standing right of the sovereign to protect itself . . . are reasonable simply by virtue of the fact that they occur at the border"). See generally B. GiLson, supra, at 151-181 (discussing the concept of a border).

ss See Note, Almeida-Sanchez and its Progeny: The Developing Border Zone Search Law, 17 ARIz. L. REv. 214, 238 n.149 (1975). See generally Schneckloth v. Bustamonte, 412 U.S. 218, 222-27 (1973) (setting forth the basic doctrine that consent is an exception to the need for a warrant).

Bo Note, Border Searches, supra note 1, at 1012.

${ }^{60}$ In United States v. Alvarez-Gonzalez, 561 F.2d 620 (5th Cir. 1977), for example, the fact that only $60 \%$ of the traffic was international was nonetheless sufficient to establish "minimal interference with domestic traffic" within the Fifth Circuit's test. Id. at 623. In United States v. Luddington, 589 F.2d 236 (5th Cir.), cert. denied, 441 U.S. 936 (1979), the court held that a checkpoint was a functional border equivalent even though no statistical evidence as to the percentage of international traffic was presented and despite the concession that "as a matter of sheer volume, the effect of the checkpoint on domestic traffic [was] significant." Id. at 241 .

61 See Almeida-Sanchez v. United States, 413 U.S. 266, 281 (1973) (Powell, J., concurring) ("One who merely travels in regions near the borders of the country can hardly be 
sulted and stigmatized, since the selection often will not reflect justified suspicion.

In sum, when viewed in light of the government's strong sovereign interests, warrantless searches at virtual border equivalents seem permissible, and indeed can sensibly be categorized as falling within the border search exception itself. But searches at distant border checkpoints present special problems because of their overinclusiveness. A theory of functional border equivalence must balance the negative effects of this overinclusiveness against the sovereign's special interests in conducting such searches.

\section{B. An Analogy to Administrative Searches}

Because neither the Supreme Court nor any other court has rigorously analyzed functional border equivalence in light of sovereign national interests, it is appropriate to look elsewhere in fourth amendment law to find a framework for balancing the competing individual and governmental interests. Such a framework can be found in the Court's decisions relating to administrative searches. In that area the Court has created a category of intermediate fourth amendment protection for searches that are overinclusive but effectuate strong government interests.

In Camara v. Municipal Court, ${ }^{62}$ the Court ruled that a warrant is generally required for searches made by government officials to determine compliance with administrative regulations. ${ }^{63}$ Although the Court acknowledged that administrative searches were a less hostile intrusion than a typical police search for criminal evidence, it reasoned that the public interest in regulating health and safety did not justify dispensing with the need for a warrant. ${ }^{64}$ Only if requiring a warrant would "frustrate the governmental purpose behind the search" may officials conduct administrative searches without a warrant. ${ }^{65}$

Consideration of the public interest did, however, lead the Court to relax the probable cause requirements that must be satis-

thought to have submitted to inspections in exchange for a special perquisite."); cf. Shapiro v. Thompson, 394 U.S. 618, 629-31 (1969) (reaffirming the right to freedom of travel within the United States).

62 387 U.S. 523 (1967).

63 Id. at 534. Administrative searches involve inspections for the purpose of determining compliance with a "regulatory scheme for the general welfare of the community." Frank v. Maryland, 359 U.S. 360, 367 (1959).

6. 387 U.S. at $530-33$.

os Id. at 533 . 
fied before an administrative search warrant could be issued. ${ }^{66}$ General area inspection warrants could be issued upon "probable cause" standards that are less stringent than those required to obtain a warrant for a criminal search. ${ }^{67}$ The standard of probable cause for any given search was held to vary with the nature of the regulatory program. ${ }^{68}$

The Court justified this modified warrant system by its assessment of the magnitude of governmental and individual interests peculiar to administrative searches. The Court found the government's interest in such searches to be unusually strong. This interest was illustrated by the historical, judicial, and public acceptance of the practice of administrative inspections, and by general notions that the public interest is served by their performance. ${ }^{69}$ The extent of intrusion on the individual, on the other hand, was found to be fairly low. These searches create a largely impersonal invasion and are not aimed at uncovering evidence of crime..$^{70}$

Camara marks the fourth amendment protections required at one point on a continuum that balances individual and governmental interests. In other cases the Court has created limited exceptions to Camara's general warrant system where the governmental interest involved was particularly strong and the type of intrusion caused by the search especially slight. If the inspections are regular and certain, pervasively monitored, or such that a warrant requirement would frustrate legitimate government enforcement goals, no warrant is required. ${ }^{71}$

so 1 d. at 534-39.

${ }^{67}$ Id. at 538. Area warrants permit the general inspection of all places or things specified within a geographical region, "based on [an] appraisal of conditions in the area as a whole, not on . . . knowledge of [the] conditions of each particular" place or thing. Id. at 536. But see See v. City of Seattle, 387 U.S. 541, 552-55 (1967) (Clark, J., dissenting). For example, the Court suggested in Camara that the mere passage of time without inspection might be sufficient to justify the issuance of a warrant. 387 U.S. at 538 .

68 387 U.S. at 538.

${ }^{69} \mathrm{Id}$. at 537.

20 Id.

71 These exceptions are gleaned from a relatively unclear line of Supreme Court cases following Camara. In Colonnade Catering Corp. v. United States, 397 U.S. 72,77 (1970), for example, the Court emphasized that because the liquor business was an industry long subject to regulation and licensing requirements, Congress had broad power to specify the kinds of warrantless inspections that would be permitted. In contrast, in United States v. Biswell, 406 U.S. 311, 315 (1972), the Court upheld a warrantless inspection of a federally licensed gun dealer even though there was no strong history of federal regulation. The Court instead stressed a consent rationale, arguing that "[w]hen a dealer chooses to engage in [a] pervasively regulated business . . . he does so with the knowledge that [he] will be subject to effective inspection." Id. at 316. In Marshall v. Barlow's, Inc., 436 U.S. 307, 324-25 (1978), however, the Court held that industrial inspections by the Occupational Safety and Health 
In addition to relaxed probable cause requirements, the administrative search doctrine also acknowledges that some search warrants may be issued even though the object of the search is not described with the particularity normally required by the fourth amendment. In the administrative search area, if the public interest is strong enough, the intrusion upon individuals minimal, and the major purpose of the search is not to expose individuals to criminal prosecution, then the Court will approve a general area search warrant that is overinclusive in order to promote the efficient enforcement of the government's regulatory plans. ${ }^{72}$

\section{The Administrative Search and the Distant Border}

Applying administrative search jurisprudence to distant border searches requires an examination of the interests of the sovereign and the individual. The relative weight of these interests will vary with the purpose and the intrusiveness of the search. This variation means that functional border equivalence should be defined in the context of particular kinds of searches.

1. Distinguishing Immigration and Customs Searches. The government stops and searches individuals at border zone checkpoints primarily for two purposes: to enforce the immigration laws and to enforce the customs laws. ${ }^{73}$ But the government's interests

Administration (OSHA) could not be conducted without a warrant. The Court explained that the Colonnade and Biswell exceptions were limited to those industries which were both pervasively regulated and had a long tradition of government supervision. The rationale for these exceptions was that only participants in an activity which is widely and historically regulated can be deemed to have given their implied consent to the warrantless inspection. Id. at 313-14. In a further shift of emphasis, the Court in Donovan v. Dewey, 452 U.S. 594, 603-06 (1981), permitted the warrantless inspection of mines by federal officials, and emphasized the certainty and regularity with which the searches occurred. The Court indicated that the flaw of the OSHA regulation in Marshall was that, unlike the mine inspection statute in Donovan, it gave too much discretion to the OSHA inspectors to determine when and whom to search. Id. at 601 .

72 Camara, 387 U.S. at 537; see Pennsylvania v. Mimms, 434 U.S. 106, 121 n.11 (1977) (Stevens, J., dissenting) (noting that regulatory searches and border searches are the two best known exceptions to the particularity requirements of the fourth amendment); United States v. Davis, 482 F.2d 893, 908 (9th Cir. 1973) ("The essence of these decisions [of the Supreme Court] is that searches conducted as part of a general regulatory scheme in furtherance of an administrative purpose, rather than as part of a criminal investigation to secure evidence of crime, may be permissible under the Fourth Amendment though not supported by a showing of probable cause directed to a particular place or person to be searched.").

73 "Immigration law" is used to mean the body of law governing the admission and deportation of aliens, and should be distinguished from the more general law of aliens' rights and obligations. See Legomsky, Immigration Law and the Principle of Plenary Congressional Power, 1984 Sup. Cr. Rev. 255, 256. "Customs law" is used to mean the body of 
differ in the two contexts.

The government has a fundamental interest in enforcing its immigration laws through border-zone searches. Immigration laws are uniquely important because a state is defined by its members and their agreement to form it. ${ }^{74}$ Membership in a specific community or state is the "central concept of politics"; the identity of the members of a community is critical to the political embodiment of that community. ${ }^{76}$

Recognition of the critical nature of the sovereign's interest in immigration is evident in early English common law. In Calvin's $\mathrm{Case}^{77}$ it was recognized that a person born alien could be made a subject only by the "denization" of the King. The power to grant citizenship was considered so inextricably bound up with the sovereign's high prerogative that it could not be delegated..$^{78}$

This conception of citizenship and nationality carried over into the late eighteenth century, when European philosophers attempted to categorize the natural law. Vattel argued that the right to prohibit entry into the country stemmed directly from the rights and domain of the sovereign. ${ }^{79}$ This domain included the right to condition entry of an alien in any manner the sovereign saw fit. ${ }^{80}$

law regulating the admission of goods and articles into the country. See United States v. Ramsey, 431 U.S. 606, 616-619 (1977).

" See Locke, Second Treatise of Government 63 (C. Sherman ed. 1937) (1st ed. London 1658) (the only way whereby anyone may divest himself of his natural liberty and join a civil society is by "agreeing with other men to join and unite in a community [and thereby] make one body politic"); P. Schuck \& R. SMrth, Citizenship Without Consent: Illegal Aliens in the American Polity 22-31 (1985); cf. Aristotle, Nicomachean Ethics Bk. VIII, chs. i, ix (Browne trans. London 1853) (discussing the importance of unanimity and friendship for success of community).

${ }^{73}$ Friedrich, The Concept of Community in the History of Political and Legal Philosophy, in Community 20 (Nomos No. 2, C. Friedrich ed. 1959); Aristotle, Politics, Bk. III, ch. iii, $\S \S 7-12$ (Barker trans. 1946) (basic identity of polis defined by its membership).

${ }_{70}$ Many of the framers were troubled by the problem of maintaining an essential homogeneity in the growing population of the nation. See, e.g., ThE Federalist No. 2, at 38-39 (J. Jay) (C. Rossiter ed. 1961); Thomas Jefferson, Notes on the State of Virginia, Query VIII, at 83-85 (W. Peden ed. 1954). See generally Alexis DE TocqueviLle, Democracy IN AMERICA 32-40 (J. Mayer ed. 1969) (discussing common features and differences among the early American colonists).

I7 7 Coke Rep. 1a, 77 Eng. Rep. 377 (1608). For an in-depth analysis of Calvin's Case, see P. Schuck \& R. SMith, supra note 74, at 12-17.

${ }^{78}$ Calvin's Case, 7 Coke Rep. at 18a, 25b. Sovereign control of immigration may also be accomplished by statute. In 1645, Massachusetts passed the first American immigration law prohibiting the immigration of the indigent and poor. EDWARD P. Hutchinson, Legislative History of American Immigration Policy 1798-1965, at 390 (1981). The Supreme Court has since ruled that the Constitution preempts state regulation or taxation of immigrants.

Chy Lung v. Freeman, 92 U.S. 275, 280 (1875).

70 See E. VATTEL, supra note $43, \S 94$.

so Id. § 100 . 
The power of exclusion was particularly important because, upon the alien's entry, the sovereign undertook the duty to protect him. ${ }^{81}$ Thus, according to natural law theorists, the sovereign had to consent to the undertaking of his natural law obligations; they could not be thrust upon him. ${ }^{82}$

The practice of international law has followed this natural law conception of sovereign powers. Roman citizenship could be extended only by edict of the sovereign. ${ }^{83}$ Similarly, modern international law tribunals have followed the principle that a state has the power to declare who are its nationals. ${ }^{84}$ This includes the power to deny foreigners the right to enter the country. Since it is through the standard of nationality that the granting of rights and the undertaking of binding obligations by a state is measured internationally, the conveyance of citizenship lies wholly within the domestic jurisdiction of each state. ${ }^{85}$

The importance of the sovereign interest in immigration is also evident in the great deference that the Supreme Court has accorded the federal government's power over immigration. The Court has held that regulation of immigration is solely a federal power, ${ }^{86}$ and has allowed the federal government latitude to take

81 Id. § 104.

82 See 2 Jean Jacques Burlamaqui, The Princlples of Natural and Politic Law 31 (5th ed. Cambridge 1807) (1st ed. Geneva 1748); cf. 2 Sir Robert J. PhIlimore, CommenTARIES Upon INTERNATIONAL LAw 3-7 (3d ed. 1882); United States v. United States District Court, 407 U.S. 297, 312 (1972) (discussing sovereign duties in the law enforcement context, the Court stated, "unless Government safeguards its own capacity . . . to preserve the security of its people . . . all rights and liberties would be endangered. . . . 'Civil liberties . . . imply the existence of an organized society maintaining public order.' ") (quoting Cox v. New Hampshire, 312 U.S. 569, 574 (1971)).

${ }^{83}$ See B. Gilson, supra note 57 , at 105 . The Roman law of jus gentium is generally recognized as the source of modern international law. Id. at 7-8.

s4 Id. at 107; see Nationality Decrees in Tunis and Morocco, 1923 P.C.I.J., ser. B, No. 4 (Advisory Opinion of Feb. 7).

${ }^{85}$ Nottebohm Case (Liechtenstein v. Guatemala) 1955 I.C.J. 4, 20 (Judgment of Apr. 6) ("it is for every sovereign State to settle . . . the rules relating to acquisition of its nationality, and to confer that nationality . . . by its own organs").

${ }^{88}$ Chy Lung v. Freeman, 92 U.S. 275, 280-81 (1875). The Court has also acknowledged the greater federal power over aliens' rights and obligations. Whereas state restrictions on welfare payments, Graham v. Richardson, 403 U.S. 365, 376 (1971), or state public employment, Sugarman v. Dougall, 413 U.S. 634, 641-46 (1973), available to aliens have been found to violate the equal protection clause of the fourteenth amendment, the Court in Mathews v. Diaz, 426 U.S. 67, 78-80 (1976), expressly acknowledged Congress's power to make rules concerning aliens that would be unacceptable if applied to citizens. Mathews upheld a rule which denied Medicare benefits to aliens who had not been admitted to and resided in the United States for five years. Id. at 83-87. Similarly, while states may only limit the public employment of aliens in those instances where the special demands of the position require citizenship, see Sugarman, 413 U.S. at 647, in Hampton v. Mow Sun Wong, 426 U.S. 88 (1976), the Court acknowledged in dicta that the "paramount federal power over immigra- 
certain actions in the immigration context that would not be allowed in other contexts. ${ }^{87}$

In comparison to this sovereign interest in immigration, the government's interest in customs enforcement appears less fundamental. Customs regulation controls only the objects that enter the nation's geographical boundary; immigration control enforces the identity of citizenship which makes the geographical boundary meaningful in the first place. Because citizenship "defines" the sovereign in a democracy, the very power to make decisions about customs control depends upon an enforceable definition of citizenship. Perhaps in recognition of this, the Supreme Court has ensured the federal government an almost limitless monopoly over the admission of aliens, ${ }^{88}$ while it has not been so troubled by state customs regulations. ${ }^{88}$ Though both immigration and customs law

tion . . . forecloses a simple extension" of the prohibition applied to the states and that "overriding national interests may provide a justification for a citizenship requirement in the federal service even though an identical requirement may not be enforced by a State." Id. at 100-01.

${ }^{87}$ In Fiallo v. Bell, 430 U.S. 787, 791-92 (1977), the Court held that Congress could give a preference in immigration to illegitimate children whose mothers were citizens without giving a similar preference based on the father's citizenship. Such a distinction, if applied to citizens outside the immigration context, would surely be invalidated on equal protection grounds. Cf. Stanley v. Illinois, 405 U.S. 645 (1972) (striking down an Illinois law that presumed the parental unfitness of unwed fathers but not that of unwed mothers). Additionally, in Kleindienst v. Mandel, 408 U.S. 753, 767-70 (1972), the Court upheld the government's decision to deny a visa to a journalist because of his Marxist views, despite its recognition that the denial implicated the first amendment interests of American citizens who wished to meet with the journalist. See also supra note 44 and accompanying text.

Although one commentator recently has criticized this "special deference [the Court] has accorded Congress in the field of immigration," Legomsky, supra note 73, at 255, the Court has not deviated from its deferential policy. Another author draws tangential support for the belief that Congress's immigration powers are waning slightly from the Supreme Court's recent decision in Plyler v. Doe, 457 U.S. 202 (1982), which invalidated a state statute that denied free public education to the children of undocumented aliens. See Schuck, supra note 48, at 54-58. This reliance is misplaced, however, since the Court in Plyler did no more than invalidate a state statutory limitation on aliens, while it cited with approval Mathews v. Diaz, 426 U.S. 67 (1976), and continued to acknowledge Congress's plenary power over the immigration field. Plyler, 457 U.S. at 210-26.

${ }^{88}$ See supra note 86 and text accompanying note 44 .

so In Frank v. Maryland, 359 U.S. 360, 367-73 (1959), the Court noted the long history of state and local customs regulations. Other courts have also recognized the states' customs powers. In rejecting a fourth amendment challenge to a search conducted at an inspection station, the California Court of Appeals did not draw any distinction between federal and state authority to conduct customs border searches. See People v. Dickinson, 104 Cal. App. 3d 505, 509-13, 163 Cal. Rptr. 575, 577-79 (1980) (approving a search conducted pursuant to state law when the defendant complied with a request that he open his trunk); cf. State v. Bailey, 120 Ariz. 399, 401, 586 P.2d 648, 649-50 (Ct. App. 1978) (approving a similar stop and search by a quarantine inspector at an agricultural inspection station pursuant to Arizona law). A state's control over the goods that cross its borders (so long as such control 
arise out of the sovereign power of a nation to control its borders, the control of immigration emerges as a significantly more important aspect of that power.

With regard to individual interests recognized by the Camara framework, immigration searches are also less intrusive than customs searches. At one time, the Fifth Circuit determined that searches of luggage and compartments too small to hold illegal aliens represented a "more serious interference [which] could well result in the striking of a different balance in determining a checkpoint's status as the functional equivalent of the border, since the degree of intrusion clearly bears on that status."90 This distinction correctly recognized the difference between immigration searches of large impersonal areas, such as the trunk of a car, and customs searches of smaller, more intimate places like a glove compartment or a piece of luggage. The nature of the objects kept in the respective places differs substantially. ${ }^{91}$ Although the Fifth Circuit has abandoned this distinction, ${ }^{22}$ it should be revived within the

does not interfere with interstate commerce), is as much an aspect of the state's sovereignty as it is of the federal government's. But see, e.g., Washington State Bldg. \& Constr. Trades Council v. Spellman, 684 F.2d 627 (9th Cir. 1982) (holding that a state restriction on the transportation of nuclear waste violates the commerce and supremacy clauses), cert. denied, 461 U.S. 913 (1983).

Examples of states exercising customs power abound. See, e.g., N.Y. VEH. \& Traf. LAW $\S 385(1)-(16)$ (McKinney 1979) (authorizing state inspection of vehicles entering the state to ensure that they satisfy size and weight regulations); Fra. STAT. § 601.29(2) (West Supp. 1985) (authorizing state inspectors to enter and examine vehicles for compliance with citrus packing regulations). Perhaps the one incident in which a state exercised a power most closely parallel to the national customs power was California's use of a quarantine in the wake of the Mediterranean fruit fly outbreak. California law authorizes the state to establish a quarantine and enforce it by maintaining inspection stations. CAL. FOOD \& AGRIC. CODE $\S \S 5301,5341$ (West 1968). Failure to stop and present any plants or quarantined items upon request is unlawful. Id. at $\$ \S 5344,5346$ (West 1968 \& Supp. 1985).

so United States v. Alvarez-Gonzalez, 561 F.2d 620, 625 (5th Cir. 1977); see also United States v. Hart, 506 F.2d 887, 895 (5th Cir.), vacated and remanded, 422 U.S. 1053 (1975), aff'd per curiam, 525 F.2d 1199, cert. denied, 428 U.S. 923 (1976).

91 This distinction is not exact. Some drugs, such as large bales of marijuana, may be concealed only in large compartments of an automobile. It is, however, unlikely that a glove compartment will conceal an illegal alien. $C f$. United States v. Chadwick, 433 U.S. 1, 12-13 (1977) (holding that lower expectations of privacy attach to an automobile than to personal luggage). A useful analogy may be drawn to the use of an arrest warrant to search a house for a criminal suspect. The search permitted under the arrest warrant is limited to large areas where the suspect may be hiding and does not include personal containers or drawers. See, e.g., Chimel v. California, 395 U.S. 752 (1969).

${ }^{82}$ See supra note 31 and accompanying text. This probably reflects the Fifth Circuit's understanding that the government's interest in permitting customs searches is the same as its interest in permitting immigration searches. See supra note 30 and accompanying text. To the extent that the Fifth Circuit's abandonment of the distinction rests on this belief, it is flawed. See supra notes 73-89 and accompanying text. Nothing precludes the Fifth Circuit 
framework of the administrative search analogy.

In addition, immigration and customs searches differ with respect to the severity of the possible consequences of the search. Violations of the customs laws carry clear criminal penalties. ${ }^{93}$ Indeed, a common customs violation, possession of narcotics, frequently results in stiff jail sentences. ${ }^{94}$ In contrast, the primary sanction for violations of federal immigration laws is deportation, ${ }^{95}$ which has long been considered a civil punishment and not a criminal sanction..$^{98}$

In sum, the balance of governmental and individual interests differs considerably in the contexts of immigration and customs searches. Immigration searches, unlike customs searches, exhibit characteristics analogous to the factors developed in Camara, which justified lower fourth amendment standards for nonparticularized, overinclusive administrative searches: they further a fundamental government interest, are not overly intrusive, and in the vast majority of cases result only in civil punishment. This suggests that immigration searches at distant border equivalents should be exempt from the full probable cause requirements of the fourth amendment, while customs searches at distant border equivalents should receive no such special treatment.

2. Warrants for distant border searches. Application of the administrative search analogy to immigration searches at distant border equivalents also suggests that no distant border search

from adopting a sovereignty interest rationale and reinstituting a distinction between immigration searches of large spaces and customs searches of small spaces.

03 See, e.g., 18 U.S.C \& 541 (1982) (up to two-year prison term for entry of falsely classified goods); id. $\$ 545$ (up to five-year prison term for smuggling).

94 The two states whose checkpoints have been most closely examined by the courts, Texas and California, have particularly harsh laws. See, e.g., Texas STAT. ANN. art. 4476-15, $\$ 4.03$ (Vernon Supp. 1985) (up to life imprisonment for sale of specified quantities of certain controlled substances); CaL. Health \& SAFETY CoDE, § 11352(a) (West Supp. 1985) (five-year to life prison term for sale of specified controlled substances).

${ }^{93}$ Federal law provides for deportation of illegal aliens, 8 U.S.C. $\$ \S 1227,1252$ (1982), and criminal sanctions against both illegal aliens, id. $\S \S 1325-26$, and those who transport them into the country, id. $\S \S 1321-24,1327-28$. Of the more than 1.1 million people apprehended for violating the immigration laws in 1983, however, only 16,493 were prosecuted, less than $2 \%$ of those arrested. Statistical ABSTract of the UnIted States, supra note 4, at $90-91$. The ensuing 11,233 convictions resulted in aggregate fines of $\$ 503,000$ and imprisonment for a total of 5,451 years. Id. at 90 . Thus, on average, a successful prosecution resulted in a punishment of a $\$ 50$ fine and 6 months imprisonment.

96 See Ingraham v. Wright, 430 U.S. 651, 668 (1977); Bugajewitz v. Adams, 228 U.S. 585,591 (1913) (Holmes, J.) (deportation is not a "punishment; it is simply a refusal by the Government to harbor persons whom it does not want"). But see Harisiades v. Shaughnessy, 342 U.S. 580, 600 (1952) (Douglas, J., dissenting) (likening deportation to banishment); Schuck, supra note 48 , at $24-27$ (contending that deportation is not merely a civil penalty). 
should be allowed unless it is authorized by an area search warrant. ${ }^{97}$ Administrative search warrants may only be dispensed with when inspections are regular and certain, where they are made in areas of pervasive regulation, or where a warrant requirement would frustrate enforcement goals. ${ }^{98}$ An examination of searches at distant equivalents of the border indicates that they do not fall within any of these exceptions: searches at distant border checkpoints are irregular and uncertain, only a small percentage of people at each checkpoint are searched, ${ }^{99}$ many distant border stations are not permanently manned, and decisions about whom and when to search necessarily involve considerable discretion by border patrol agents. ${ }^{100}$

${ }^{97}$ In Almeida-Sanchez v. United States, 413 U.S. 266, 270-72 (1973), the Court rejected the contention that the administrative search doctrine supported the constitutionality of warrantless roving border patrol searches. The Court stressed that driving an automobile near the border is not a pervasively regulated activity where the nature of the activity gives rise to an expectation that a search will occur. Id. at 271-72. The Court also noted that there is no certainty that the people being searched have engaged in the suspected activity that gives rise to the search authority, since not all people near the border have crossed it. Id.

However, the Court quite clearly left open the possibility that the administrative search doctrine would be sufficient to permit some interior border searches under an area warrant. See id. at 270 \& n. 3 (plurality opinion); id. at 283-85 (Powell, J., concurring) (suggesting the use of area warrants); id. at 288 (White, J., dissenting) (agreeing with Justice Powell).

${ }^{83}$ See supra note 71 and accompanying text.

${ }_{99}$ United States v. Ortiz, 422 U.S. 891, 896 (1975); United States v. Baca, 368 F. Supp. 398, 412-15 (S.D. Cal. 1973).

${ }^{100}$ See Ortiz, 422 U.S. at 895-96; cf. Marshall v. Barlow's Inc., 436 U.S. 307, 323 (1978) (warrant required under the Occupational Safety and Health Act in order to protect against the administrative officers" "almost unbridled discretion . . . as to when to search and whom to search"). It is not clear, however, that a random search on the highway at a fixed checkpoint involves a constitutionally excessive amount of discretion. See, e.g., Delaware v. Prouse, 440 U.S. 648, 663 (1979) (suggesting that warrantless license check stops by police at fixed checkpoints might be constitutional); State v. Deskins, 234 Kan. 529, 541-42, 673 P.2d 1174, 1184-85 (1983) (approving warrantless drunk driving checkpoints); State v. Coccomo, 177 N.J. Super. 575, 581-84, 427 A.2d 131, 134-35 (Super. Ct. Law Div. 1980) (approving warrantless license checks of every fifth car to pass through a fixed police checkpoint); People v. Ingle, 36 N.Y.2d 413, 414-15, 330 N.E.2d 39, 40, 369 N.Y.S.2d 67, 69 (1975) ("absent reasonable suspicion of a vehicle violation ... [warrantless license checks are] permissible only when conducted according to nonarbitrary, nondiscriminatory, uniform procedures for detecting violations"); cf. United States v. Albarado, 495 F.2d 799, 806 (2d Cir. 1974) (approving airport metal detector searches); United States v. Davis, 482 F.2d 893, 910 (9th Cir. 1973) (same).

Some states have invalidated warrantless checkpoints when officers operating them had been given too much discretion, without rejecting the propriety of such stops altogether. See, e.g., State ex rel. Ekstrom v. Justice Court, 136 Ariz. 1, 5, 663 P.2d 992, 996 (1983); Commonwealth v. McGeoghegan, 389 Mass. 137, 144, 449 N.E.2d 349, 353 (1983); State v. Marchand, 104 Wash. 2d 434, 706 P.2d 225 (1985) (en banc) (striking down police spot checks of vehicles to examine licenses, registrations, and equipment as vesting too much discretion in the patrolmen). In South Dakota, police cannot establish a checkpoint to identify drunk drivers without first obtaining a warrant. State v. Olgaard, 248 N.W.2d 392 (S.D. 
In addition, the requirement of a warrant for immigration searches at distant border stations is not likely to frustrate governmental interests. Aliens will not try to enter the country more often if the government must receive judicial approval for distant border searches, nor will it be difficult for the government to obtain an area warrant. This is particularly true if the judicial scrutiny occurs before a checkpoint is established. Once a determination has been made that a certain location meets the investigatory needs of the government without undue intrusion on private interests, there is no need to reevaluate the checkpoint continually. The circumstances which made it an acceptable location do not change rapidly over time. ${ }^{101}$

Moreover, it would also be possible to relax the probable cause requirement, as has been done with administrative searches. ${ }^{102}$ The standards by which a judge or magistrate would evaluate a request for an area warrant are easily discernible and not difficult to establish. Justice Powell's concurring opinion in Almeida-Sanchez suggests some possibilities:

(i) the frequency with which aliens illegally in the country are known or reasonably believed to be transported within a particular area; (ii) the proximity of the area in question to the border; (iii) the extensiveness and geographic characteristics of the area, including the roads therein and the extent of their use; and (iv) the probable degree of interference with the rights of innocent persons, taking into account the scope of the proposed search, its duration, and the concentration of illegal alien traffic in relation to the general traffic of the road or area. ${ }^{103}$

Given the strength of the government's interest in immigration searches at distant functional border equivalents, the judge or magistrate should also consider the extent to which the proposed search will help to vindicate the government's obligation to maintain the nation's sovereignty and territorial integrity by preventing illegal border crossings. ${ }^{104}$

1976).

${ }^{101}$ Cf. United States v. Dreyfus-de Campos, 698 F.2d 227, 229 (5th Cir.) (declining to reevaluate a functional border equivalent without a demonstration of changed circumstances), cert. denied, 461 U.S. 947 (1983).

${ }^{102}$ See supra notes 66-68 and accompanying text.

103 Almeida-Sanchez, 413 U.S. at 283-84 (Powell, J., concurring) (footnote omitted).

104 One necessary difference between the warrant process for distant border searches and that for administrative searches lies in the scope of the judicial function. Camara did 
These factors taken together provide a suitable framework in which to balance the sovereign interest in enforcing immigration laws against the overinclusive nature of the search. Allowing immigration searches at distant border equivalents, but only with prior judicial scrutiny, provides sufficient checks to prevent the abuse of fourth amendment rights by border patrol agents yet permits the maintenance of territorial sovereignty. ${ }^{105}$

\section{CONCLUSION}

Border searches have a long history of public and judicial acceptance. On this historical basis alone, border searches have been found exempt from the fourth amendment's prohibition against "unreasonable" searches. Yet the constitutional limitations on "border" searches that are conducted within the interior of the country at functional border equivalents remain undefined. A pure historical rationale for the border search exception provides no guidance; instead, principled limits upon searches at border equivalent checkpoints can only be understood by reference to the true purpose of border searches-maintaining national sovereignty through limits on the immigration of aliens and the influx of contraband.

Searches may be undertaken at checkpoints that constitute virtual or distant border equivalents. Customs and immigration searches conducted without a warrant at virtual border equivalents fall squarely within the border search exception and thus are not

not envision judicial scrutiny of the "basic agency decision to canvass [a particular] area." 387 U.S. at 532. The judicial function here proposed would necessarily include passing on exactly these basic decisions. Cf. Almeida-Sanchez, 413 U.S. at 282-83 (Powell, J., concurring).

${ }^{105}$ The test proposed by this comment resembles the Fifth Circuit's current practice of scrutinizing distant border equivalent designations, but differs in several significant respects. First, this test requires prior judicial scrutiny and the issuance of a warrant. This procedure protects against invasion of private interests by ensuring review of the justification for the checkpoint before it is established. In contrast, ex post judicial review can prevent only the use of unlawfully obtained evidence, not the unlawful intrusion by which that evidence was obtained. Second, this test compares the checkpoint site proposed by the INS with other possible locations that might be used. The Fifth Circuit's analysis involves no comparative factors and simply makes an isolated determination whether a particular site meets the stated requirements. Third, this test, unlike the Fifth Circuit's analysis, is informed by explicit consideration of the important role national sovereignty interests play in determining the propriety of a distant border equivalent designation. Most importantly, this test limits the scope of the searches permitted at distant border equivalents. It distinguishes immigration searches from the more intrusive and less justifiable customs searches of personal luggage or containers. The latter searches would no longer be permitted at distant border checkpoints without full fourth amendment safeguards. 
subject to fourth amendment requirements. Because of their overinclusiveness, however, searches at distant border locations are best considered through the analytic framework used to assess administrative searches. The resulting balance between the individual's privacy and autonomy interests and the sovereign interests of the government suggests that customs searches at distant border equivalents should not be allowed without full fourth amendment safeguards. Immigration searches, in contrast, should be permitted at distant border equivalents whenever they are undertaken pursuant to a valid area warrant, which may be granted under a reduced standard of probable cause.

Paul S. Rosenzweig 